\title{
Stock Assessment and Potential management of Sardinella aurita Fisheries in the East Mediterranean sea (North Sinai coast).
}

\author{
Nabil. F. Abd EL Hakim ${ }^{1}$; Attaia. A. omar ${ }^{2}$; Mohsen. S. Hussein ${ }^{1}$; Salah, M. \\ Kamal $^{3}$; Mohammed. G. Desoukt ${ }^{3}$; Hosam M. Agouz ${ }^{3}$. \\ 1- Fcaulty of Agriculture, AL-Azhar University, Cairo, Egypt. \\ 2- General Authority for Fisheries Resources Development, EL-Arish, North \\ Sinai, Egypt. \\ 3- Department of Aquaculture, Central Laboratory for Aquaculture Research, \\ Abbassa, Abo-Hammad, Shrkia, Egypt.
}

\section{ABSTRACT}

Age, growth and population biology of Sardinella aurita were studies from a small fishery of East Mediterranean Sea (North Sinai coast). 4450 specimens ranged between 6 and $22.9 \mathrm{~cm}$ total length and varied from 3 to $77.1 \mathrm{~g}$ total weight, were collected from January to December, 2010. The relationship between length and weight was estimated as $\mathrm{W}=0.016 \mathrm{~L}^{2.611}$. Age was determined using scales reading technique and the longevity of this species was found to be 4 years. Growth in length and in weight at the end of each year were calculated. The growth parameters of the Von-Bertalanffy equation were calculated as $\mathrm{L} \infty=28.37 \mathrm{~cm}, \mathrm{~K}=0.2336 \mathrm{Yr}^{-1}$ and $\mathrm{t}_{0}=-$ 0.9808 Yr. Growth performance index $\varnothing$ was estimated as 2.2742. Total, natural and fishing mortality rates were $0.99 .7 \mathrm{Yr}^{-1}, 0.3507 \mathrm{Yr}^{-1}$ and $0.53 \mathrm{Yr}^{-1}$ respectively. The currently exploitation rate $(\mathrm{E}=0.6)$ indicate that the stock of $S$. aurita in North Sinai fishery is not overexploitation. The mean index of growth performance is lower than that for the another regions this may be related to unsuitable environment.

Keywords: Sardinella aurita; growth; mortality; East Mediterranean sea.

\section{INTRODUCTION}

Family Clupeidae are of the most essential Kinds for catching in the Western part of the Mediterranean. In the off-shore waters of Italy, France and Spain (BenTuvia, 1958) fishery is based on it. In Egypt, S. pichardus and S. aurita were of the greatest importance due to the absence of $S$. pilchardus as well as its small sizes, and this species is of little commercial value in the investigated area. In spite of the round sardinella, $S$. aurita is the most important (about $86 \%$ of total catch) in Mediterranean coast of Sinai fishery, there is a little information on fishery of this species.

The aim of this study is to provide detailed assessment of the fisheries for $S$. Aurita in the East Mediterranean sea (North Sinai) by:

1- Assessing the exploitation status of the spices.

2- Management of its fisheries through the use of length analysis and yield per recruit based on the demographic structure of the catch and biological parameters for the species.

The sensitivity of the results to the natural mortality value has been also tested. 


\section{MATERIAL AND METHODS}

The fish resources of the Mediterranean coast of Sinai is exploited by three main fishing gears, the Purse-seine nets (53 Units), Trammel nets (164 Units) and Long line gear (9 Units).

This study was carried out during the period from January to December (2010). During this period, an extensive data collection program was applied, through recording the information on the fishing fleet operating in the Mediterranean coast of Sinai. The data of the catch weekly recorded for each species or species fish category for the different fishing gears. The fishing data for the previous period from 1989 to 2009 were collected from the General Authority for fish Resources Development (GAFRD) reports. The commercial catch was classified into sixteen fish categories; i.e. Sardine Spp., Crabs, Cattle fish, small shrimp, Horse mackerel, Shrimp, Cartilaginous, Fish, Sigans, Spanish mackerel, Indian Mackerel, Mullets, Snapper, Groupers, Kawakaw, Trash fish and Others.

For biological parameters, 4450 fish individuals of both sexes combined of Sardinella aurita were collected monthly from January to December 2010. The measurements as total length to the nearst millimeter and total weight to the nearest one gram of the fish were recorded for each specimen. For age determination, the scale samples were removed from the left side of each fish behind the tip of pectoral fin for 4450 specimens. (Paul, 1968).

Parameters estimate are taken from the biological studies on the Sardinella aurita including Von-Bertalanffy (1934) growth curves ( $\mathrm{L} \infty, \mathrm{K}$ and $\left.\mathrm{t}_{0}\right)$, length-weight relationship, length at sexual maturity $\left(\mathrm{L}_{50}\right)$, natural mortality $(\mathrm{M})$ and fish mortality (F).

\section{1-Length-weight relationship:}

The relationship between length and weight was described by the equation $\left(\mathrm{W}=\mathrm{CL}^{\mathrm{n}}\right)$, where $\mathrm{W}$ is the total weight (g.) and $\mathrm{L}$ is the total length (cm.), $\mathrm{C}$ and $\mathrm{n}$ constants (Martin, 1949).

\section{2-Scales preparation and Age determination:}

In the laboratory, the scales were cleaned and stored dry in envelopes for the subsequent study. Later on, scales were $\varnothing$ for the soaked overnight in $10 \%$ ammonia solutions. 5-7 scales were placed between tow glass slides, and examined by a projector with $33 \mathrm{X}$ magnification. The total radius of the scale of the longer axis as well as the distance form the focus of the scale to the successive annuli were measured to the nearest $0.01 \mathrm{~cm}$. According to Whitney and Calender (1956), the best regression to use was that of fish length and average scale radius as:

$$
\mathrm{L}=\mathrm{a}+\mathrm{bR}
$$

Where: $\mathrm{L}$ is total length of fish in $\mathrm{cm}$.

$\mathrm{R}$ is magnified scale radius in $\mathrm{cm}$. (a) and (b) constants representing the intercept and the slope of straight line respectively.

\section{3-the back-calculated:}

The length at previous ages, were back calculated from scale measurements using Lea's equation (1910): $\mathrm{Ln}=(\mathrm{Sn} / \mathrm{S}) \mathrm{L}$ where

$\mathrm{Ln}=$ is length of fish at age " $\mathrm{n}$ "

$\mathrm{Sn}=$ is magnified scale radius to " $\mathrm{n}$ " annuals

$\mathrm{S}=$ is magnified total scale radius

$\mathrm{L}=$ is first length at capture

\section{4- Growth parameters:}

The Von-Bertalanffy models, (1934 and 1949), $\mathrm{L}_{\mathrm{t}}=\mathrm{L} \infty\left(1-\mathrm{e}^{-\mathrm{K}[\mathrm{t}-\mathrm{t} 0]}\right)$ 
Was used to describe growth in size, where $\mathrm{L}_{\mathrm{t}}$ is the length at age $t, \mathrm{~L} \infty$ the asymptotic length, $\mathrm{K}$ the body growth coefficient and defines the growth rate towards $\mathrm{L} \infty$ and $\mathrm{t}_{0}$ the hypothetical age at which a fish would have zero Length the values of $\mathrm{L} \infty, \mathrm{K}$ and $\mathrm{t}_{0}$ were estimated by Plotting $\mathrm{L}_{\mathrm{t}}$ VS $\mathrm{L}_{\mathrm{t} 11}$ using the Ford (1933), Walford (1946) procedure. The growth performance index was calculated by using the Phiprime test $\left(\varnothing^{\prime}\right)=\log K+2 \operatorname{LogL} \infty$ (Munor and Pauly, 1983) which can be used to compare growth performance under environmental stresses (Pauly, 1994).

\section{5- Mortality rates:}

Total mortality (Z) was estimated by a method of Pauly (1980) as $\mathrm{LnN}=\mathrm{a}+\mathrm{bt}$ where Ln is natural Logarithmic of the number of fish in the sample $(\mathrm{N})$ against their respective age $(\mathrm{t})$ and $\mathrm{a}$ and $\mathrm{b}$ are constants.

Natural mortality coefficient was estimated by using the equation of Pauly (1980), $\log M=[-0.0066-0.279 \log L \infty+0.6543 \log K+0.4634 \log T]$.

Fishing mortality coefficient $(\mathrm{F})$ was estimated directly by subtracting the value of the natural mortality from the value of the mean total mortality as $\mathrm{F}=\mathrm{Z}-\mathrm{M}$.

6- The Exploitation rate (E):

Estimation the exploitation rate (E) can be estimated by Gulland (1971) equation: $\mathrm{E}=\mathrm{F} /(\mathrm{F}+\mathrm{M})$, where $\mathrm{E}$ is exploitation rate, $\mathrm{F}$ is fishing mortality and $\mathrm{M}$ is natural mortality.

\section{7- Recruitment and yield per recruit:}

Recruitment is the process by which young fish enter the exploited area and become liable to contact with fishing gear. It can be estimated by equation of Gulland (1969):

$\mathrm{R}=\mathrm{R} / \mathrm{em}$ (tc-tr)

Where:

$\mathrm{R}$ is the number of recruits, i.e. the number of fish a live at age $\mathrm{Tr}$.

$\mathrm{R} \backslash$ is the number of fish a live at the age Tc at which they are first retained by the gear in.

$\mathrm{M}$ is the natural mortality

Tc is the age at first capture

$\mathrm{Tr}$ is the age at recruitment

$\mathrm{R} \backslash=\mathrm{C}(\mathrm{F}+\mathrm{M}) / \mathrm{F}$

Where $\mathrm{C}$ is the annual catch number

Concerning to the yield per recruit of Sardinella aurita it was calculated by Gulland (1969) and Marten (1978).

\section{RESULTS}

The data of the annual variation in fish yield composition in the East Mediterranean sea (North Sinai) during the period from 1989 to 2010 are given in table (1).

Sardinella aurita, which had the most important value in the catches of north Sinai coast is amounted to 928 tons and representing $83 \%$ of the total catch during 1989. But thereafter, catches of Sardines decreased to around $51-77.9 \%$ of the total catch from 1990-1996. Then they increased during 1997 and reached 3819 (93.5\%) during 2001. A slight decreased in Sardine production took place during 2005 reaching only 783 Tons (73.2\%). Then increased during 2005 reaching 3241 tons (93.7\%).Vigorously dropped to only 219.1 tons (19.5\% of the total catch) during 2010. 
Crabs had the second important value during the period from 1989 to 2010 . Production of crabs gradually increased and reaching its maximum amount 334.1 tons (29.7\%) during 2010.

The production of cattle fish fluctuated during the period from 1989 to 2010 between 2.0 tons $(0.2 \%$ in 1989$)$ and 88 tons $(2.4 \%$ in 2008$)$.

Spanish mackerel, Groupers and others were greatly varied according to their importance in the total yield of the North Sinai fishery, during the period of study.

Table 1: The Annual variation in the total fish yield composition of the Mediterranean coast of Sinai from 1989 to 2010.

\begin{tabular}{|c|c|c|c|c|c|c|c|c|c|c|c|c|c|c|c|}
\hline \multirow[t]{2}{*}{ Year } & \multicolumn{2}{|c|}{ Sardine } & \multicolumn{2}{|c|}{$\begin{array}{c}\text { Med. Horse } \\
\text { Mackerel }\end{array}$} & \multicolumn{2}{|c|}{$\begin{array}{l}\text { Spanish } \\
\text { Mackerel }\end{array}$} & \multicolumn{2}{|c|}{ Groupers } & \multicolumn{2}{|c|}{ Cattle fish } & \multicolumn{2}{|c|}{$\mathrm{Crab}$} & \multicolumn{2}{|c|}{ Others } & \multirow{2}{*}{$\begin{array}{l}\text { Total } \\
\text { yield }\end{array}$} \\
\hline & Ton & $\%$ & Ton & $\%$ & Ton & $\%$ & Ton & $\%$ & Ton & $\%$ & Ton & & Ton & $\%$ & \\
\hline 1989 & 928.0 & 83.0 & 5.0 & 0.4 & 2.0 & 0.2 & 23.0 & 2.1 & 2.0 & 0.2 & 1.0 & 0.1 & 157.0 & 14.0 & 1118 \\
\hline 1990 & 310.0 & 51.0 & 12.0 & 2.0 & 34.0 & 5.6 & 26.0 & 4.3 & 32.0 & 5.3 & 3.0 & 0.5 & $\begin{array}{l}191.0 \\
\end{array}$ & 31.4 & 608 \\
\hline 1991 & 25.0 & 70.9 & 44.0 & 4.3 & 43.0 & 4.2 & 20.0 & 2.0 & 10.0 & 1.0 & 3.0 & 0.3 & 177.0 & 17.3 & 1022 \\
\hline 1992 & 247.0 & 87.7 & 15.0 & 0.6 & 9.0 & 0.4 & 29.0 & 1.1 & 47.0 & 1.8 & 8.0 & 0.3 & 208.0 & 8.1 & 2563 \\
\hline 1993 & 543.0 & 82.4 & 21.0 & 1.1 & 7.0 & 0.4 & 34.0 & 1.8 & 46.0 & 2.5 & 3.0 & 0.2 & 218.0 & 11.6 & 1872 \\
\hline 1994 & 2003.0 & 83.7 & 70.0 & 2.9 & 12.0 & 0.5 & 13.0 & 0.5 & 44.0 & 1.8 & 17.0 & 0.7 & 233.0 & 9.7 & 2392 \\
\hline 1995 & 240.0 & 79.1 & 53.0 & 3.4 & 9.0 & 0.6 & 17.0 & 1.1 & 23.0 & 1.5 & 3.0 & 0.2 & 223.0 & 14.2 & 1568 \\
\hline 1996 & 993.0 & 77.9 & 57.0 & 4.5 & 25.0 & 2.0 & 12.0 & 0.9 & 44.0 & 3.5 & 3.0 & 0.2 & 140.0 & 11.0 & 1274 \\
\hline 1997 & 2568.0 & 90.1 & 105.0 & 3.7 & 14.0 & 0.5 & 16.0 & 0.6 & 37.0 & 1.3 & 14.0 & 0.5 & 97.0 & 3.4 & 2851 \\
\hline 1998 & 5014.0 & 95.0 & 38.0 & 0.7 & 9.0 & 0.2 & 11.0 & 0.2 & 49.0 & 0.9 & 9.0 & 0.2 & 148.0 & 2.8 & 5278 \\
\hline 1999 & 11478. & 98.0 & 58.0 & 0.5 & 3.0 & 0.0 & 7.0 & 0.1 & 25.0 & 0.2 & 4.0 & 0.0 & 140.0 & 1.2 & 11715 \\
\hline 2000 & 3293.0 & 84.4 & 37.0 & 0.9 & 19.0 & 0.5 & 7.0 & 0.2 & 24.0 & 0.6 & 4.0 & 0.1 & 517.0 & 13.3 & 3901 \\
\hline 2001 & 3817.0 & 93.5 & 58.0 & 1.4 & 11.0 & 0.3 & 11.5 & 0.3 & 22.0 & 0.5 & 12.0 & 0.3 & 152.5 & 3.7 & 4084 \\
\hline 2002 & 1300.0 & 77.4 & 60.1 & 3.6 & 19.6 & 1.2 & 17.1 & 1.0 & 49.1 & 2.9 & 27.7 & 1.6 & 206.8 & 12.3 & 1680.4 \\
\hline 2003 & 1025.0 & 73.2 & 96.0 & 6.9 & 10.0 & 0.7 & 17.0 & 1.2 & 93.0 & 6.6 & 54.0 & 3.9 & 105.0 & 7.5 & 1400 \\
\hline 2004 & 827.0 & 69.7 & 113.8 & 9.6 & 8.2 & 0.7 & 14.8 & 1.2 & 46.9 & 4.0 & 11.4 & 1.0 & 165.0 & 13.9 & 1187.1 \\
\hline 2005 & 783.0 & 73.2 & 39.0 & 3.6 & 18.0 & 1.7 & 21.0 & 2.0 & 70.0 & 6.5 & 43.0 & 4.0 & 95.0 & 8.9 & 1069 \\
\hline 2006 & 3241.0 & 93.7 & 15.0 & 0.4 & 5.0 & 0.1 & 6.0 & 0.2 & 56.0 & 1.6 & 71.0 & 2.1 & 64.0 & 1.9 & 3458 \\
\hline 2007 & 1950.0 & 83.4 & 73.0 & 3.1 & 15.0 & 0.6 & 10.0 & 0.4 & 74.0 & 3.2 & 77.0 & 3.3 & 139.0 & 5.9 & 2338 \\
\hline 2008 & 3014.0 & 83.8 & 53. & 1.5 & 20.0 & 0.6 & 10.0 & 0.3 & 88.0 & 2.4 & 180. & 5.0 & 231.0 & 6.4 & 3596 \\
\hline 2009 & 1032.0 & 62.0 & 15.0 & 0.9 & 15.0 & 0.9 & 11.0 & 0.7 & 74.0 & 4.4 & 258. & 15.5 & 260.0 & 15.6 & 1665 \\
\hline 2010 & 219.1 & 19.5 & 69 & 6.2 & 19.2 & 1.8 & 8.4 & 0.7 & 82.0 & 7.2 & 334.1 & 29.7 & 392.9 & 35 & 1125 \\
\hline Average & 2252 & 86 & 50 & 1.9 & 15 & 0.6 & 16 & 0.6 & 47 & 1.8 & 52 & 2.0 & 194 & 7.4 & 2626 \\
\hline
\end{tabular}

\section{Biological parameters}

\section{1- Length-weight relationship:}

The observed total length of 4450 Sardinella aurita caught from north Sinai coast from January to December 2010 ranged from 6 to $23.9 \mathrm{~cm}$ and the observed total weight from 3 to $77.1 \mathrm{~g}$. (Table 2). The length weight relationship (Fig. 1) was described by the power equation as:

$\mathrm{W}=0.0158 \mathrm{~L}^{2.6821}$

To avoid the bias which may be caused by the weight of stomachs, gonads and their seasonal variation, the length-weight relationship were estimated using the gutted weight by equation. $\mathrm{W}=0.016 \mathrm{~L}^{2.6411}$ (Fig. 2).

\section{2- Body length-scale radius relationship:}

4450 specimen were collected for ageing and growth analysis. Age estimated ranged between 0-5 years, age-length Key were calculated (Table 3). The mean fish length and the average scale radius per each length group are given with the ratio of fish length to scale size in (Fig. 3). Data for S. aurita between fish length and scale radius show a linear trend on their scatter diagram where described by the equation: $\mathrm{L}=-0.6683+2.1321 \mathrm{~S}$ 
Table 2: Observed and calculated total weight and gutted weight for combined sexes S. aurita 2010 in Mediterranean cost of Sinai

\begin{tabular}{|c|c|c|c|c|c|c|}
\hline No. of fish & T. L & ML & \multicolumn{2}{|c|}{ T. W. in gm } & \multicolumn{2}{c|}{ Gutted W. in gm } \\
\hline & & & $\begin{array}{c}\text { Av. T. W. } \\
\text { Observed }\end{array}$ & Calculated T. W. & $\begin{array}{c}\text { Av. gutted W. } \\
\text { Observed }\end{array}$ & Calculated gutted W. \\
\hline 100 & $6-6.9$ & 6.7 & 3.0 & 2.5 & 2.7 & 2.4 \\
\hline 174 & $7-7.9$ & 7.8 & 3.9 & 3.9 & 3.6 & 3.6 \\
\hline 216 & $8-8.9$ & 8.8 & 4.7 & 5.3 & 4.4 & 6.9 \\
\hline 270 & $9-9.9$ & 9.7 & 6.2 & 7.0 & 5.7 & 7.7 \\
\hline 624 & $10-10.9$ & 10.4 & 8.5 & 8.4 & 8.0 & 10.3 \\
\hline 256 & $11-11.9$ & 11.6 & 11.2 & 11.2 & 13.0 & 12.6 \\
\hline 348 & $12-12.9$ & 12.5 & 14.6 & 13.8 & 15.3 & 17.8 \\
\hline 596 & $13-13.9$ & 13.3 & 16.5 & 16.3 & 17.4 & 22.4 \\
\hline 432 & $14-14.9$ & 14.3 & 18.7 & 19.7 & 23.0 & 25.5 \\
\hline 566 & $15-15.9$ & 15.5 & 25.0 & 24.7 & 32.6 & 30.2 \\
\hline 134 & $16-16.9$ & 16.3 & 26.6 & 28.2 & 36.5 & 35.1 \\
\hline 152 & $17-17.9$ & 17.4 & 34.9 & 33.5 & 40.9 & 40.3 \\
\hline 104 & $18-18.9$ & 18.4 & 40.0 & 39.1 & 44.2 & 45.0 \\
\hline 268 & $19-19.9$ & 19.4 & 45.0 & 44.9 & 49.5 & 51.6 \\
\hline 30 & $20-20.9$ & 20.2 & 51.6 & 50.3 & 53.3 & 57.5 \\
\hline 78 & $21-21.9$ & 21.3 & 56.4 & 57.7 & & 64.2 \\
\hline 86 & $22-22.9$ & 22.2 & 61.2 & 64.5 & & \\
\hline 16 & $23-23.9$ & 23.1 & 77.1 & 72.1 & & \\
\hline 4450 & & & & & & \\
\hline
\end{tabular}
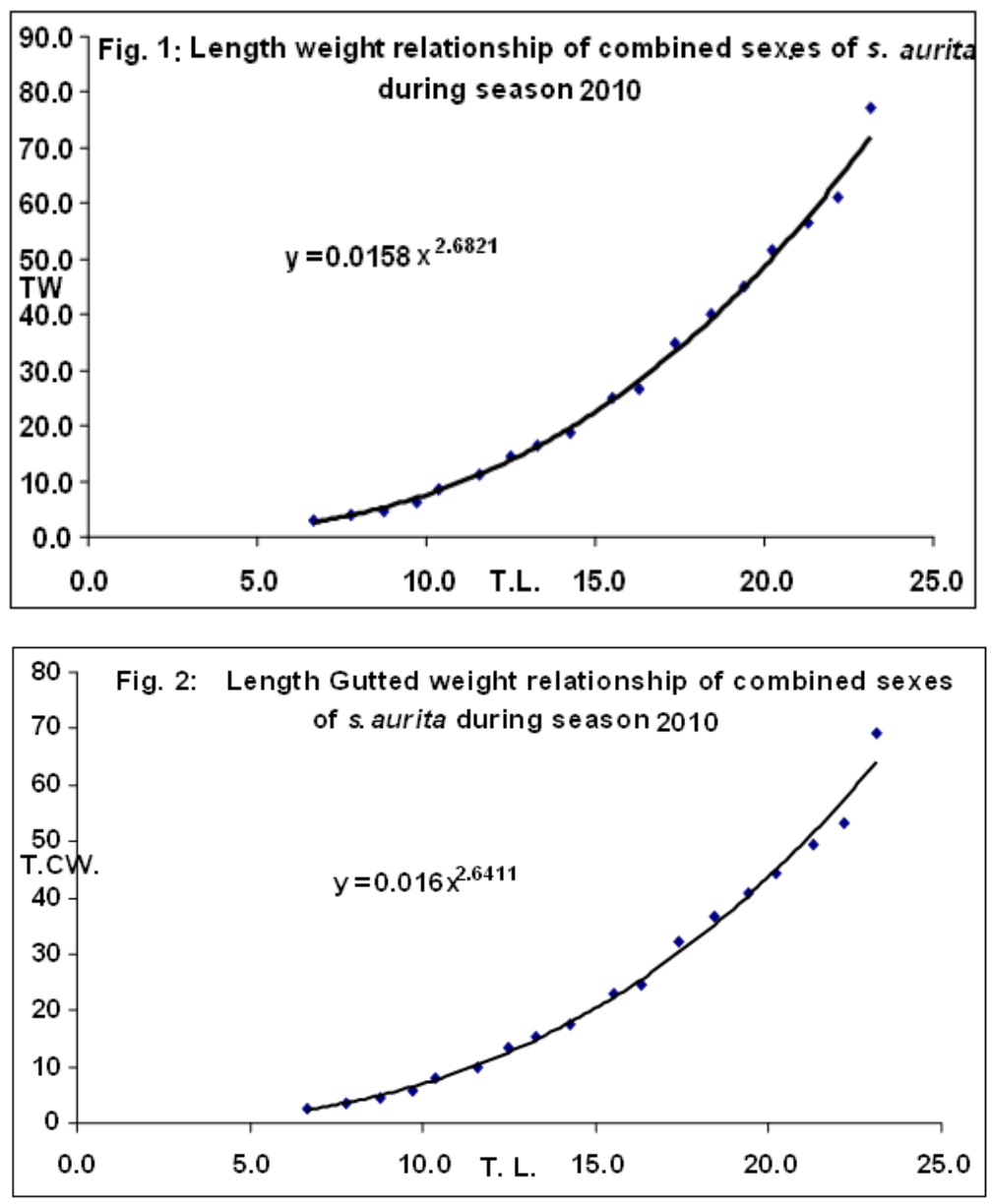
Table 3: Age-length key of combined sexes of S. aurita during season 2010.

\begin{tabular}{|l|l|l|l|l|l|l|l|l|}
\hline & age0 & age1 & age2 & age3 & age4 & age5 & NI & Pi \\
\hline $6-6.9$ & 100 & & & & & & 100 & 2.2 \\
\hline $7-7.9$ & 174 & & & & & & 174 & 3.9 \\
\hline 8.8 .9 & 216 & & & & & & 216 & 4.9 \\
\hline $9-9.9$ & 270 & 0 & & & & & 270 & 6.1 \\
\hline $10-10.9$ & 130 & 494 & & & & & 624 & 14.0 \\
\hline $11-11.9$ & & 256 & & & & & 256 & 5.8 \\
\hline $12-12.9$ & & 316 & 32 & & & & 348 & 7.8 \\
\hline $13-13.9$ & & & 596 & & & & 596 & 13.4 \\
\hline $14-14.9$ & & & 392 & 40 & & & 432 & 9.7 \\
\hline $15-15.9$ & & & 454 & 112 & & & 566 & 12.7 \\
\hline $16-16.9$ & & & & 134 & & & 134 & 3.0 \\
\hline $17-17.9$ & & & & 122 & 30 & & 152 & 3.4 \\
\hline $18-18.9$ & & & & 80 & 24 & 0 & 104 & 2.3 \\
\hline $19-19.9$ & & & & 130 & 106 & 32 & 268 & 6.0 \\
\hline $20-20.9$ & & & & & 20 & 10 & 30 & 0.7 \\
\hline $21-21.9$ & & & & & 44 & 34 & 78 & 1.8 \\
\hline $22-22.9$ & & & & & 24 & 62 & 86 & 1.9 \\
\hline $23-23.9$ & & & & & & 16 & 16 & 0.4 \\
\hline total & 890 & 1066 & 33.1 & 618 & 248 & 154 & 4450 & 100.0 \\
\hline
\end{tabular}

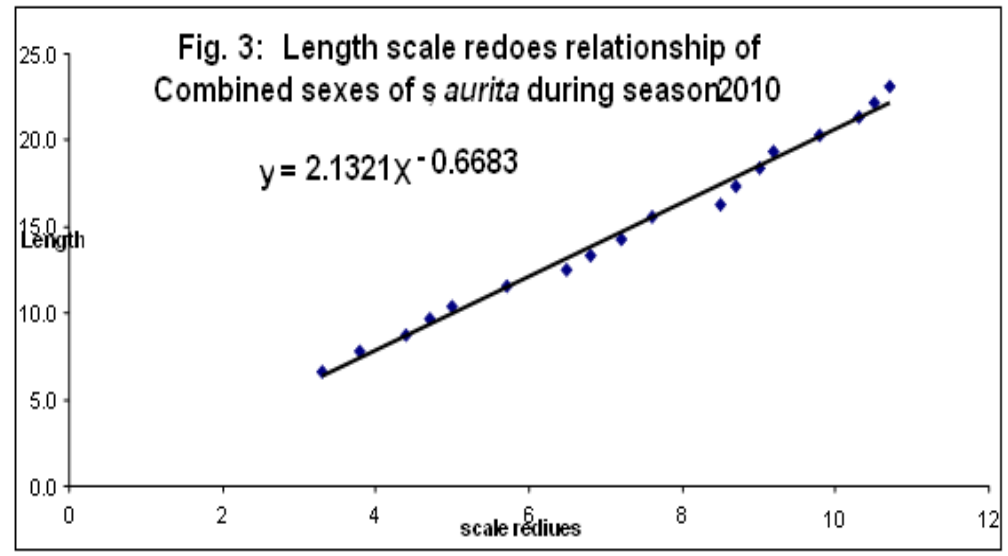

\section{3- The back-calculations:}

The average back-calculation length and annual increment of the combined sexes (Table 4) are 10.6, 14.23, 17,26 and $19.66 \mathrm{~cm}$ for age 1, 2, 3, and 4 respectively. The highest annual increment occurred during the first year of life, while a noticeable decrease is observed in the second year, reaching its minimal value during the fourth year of life.

Table 4: Back-calculation length at the end of different years of life of combined sexes ( $\left(0^{\top}\right)$ of $S$. aurita (2010)

\begin{tabular}{|c|c|c|c|c|c|c|}
\hline Age group & No. of fish & \multicolumn{6}{|c|}{ Average calculated lengths at the end of each year $(\mathrm{cm})$} \\
\hline 0 & 760 & I & II & III & IV & V \\
\hline I & 1196 & 10.60 & & & & \\
\hline II & 1474 & 10.59 & 14.23 & & & \\
\hline III & 618 & 10.41 & 14.19 & 17.26 & & \\
\hline IV & 248 & 10.63 & 14.23 & 17.31 & 19.66 & \\
\hline V & 154 & 10.44 & 14.27 & 17.25 & 19.61 & 21.38 \\
\hline Increment & 4450 & 10.60 & 3.63 & 3.03 & 2.40 & 1.72 \\
\hline
\end{tabular}


The average back-calculation weights at the end of each year of life for $S$. aurita were estimated by applying the length-weight relationship and the results are given in (Table 5 and Fig 4).

Table 5: Average estimated weight and increment of weight at during, 2010 of combined sexes of $S$. aurita.

\begin{tabular}{|l|l|l|l|l|l|l|}
\hline Age group & No. of fish & \multicolumn{5}{|c|}{ Average estimated weight at the end of each year(gm ) } \\
\hline & 760 & I & II & III & IV & V \\
\hline I & 1196 & 8.9 & & & & \\
\hline II & 1474 & 8.9 & 19.6 & & & \\
\hline III & 618 & 8.5 & 19.4 & 32.8 & & \\
\hline IV & 248 & 9.0 & 19.6 & 33.1 & 46.6 & \\
\hline V & 154 & 8.5 & 19.7 & 32.8 & 46.3 & 58.3 \\
\hline Increment & 4450 & 11.4 & 10.7 & 13.3 & 13.7 & 11.7 \\
\hline
\end{tabular}

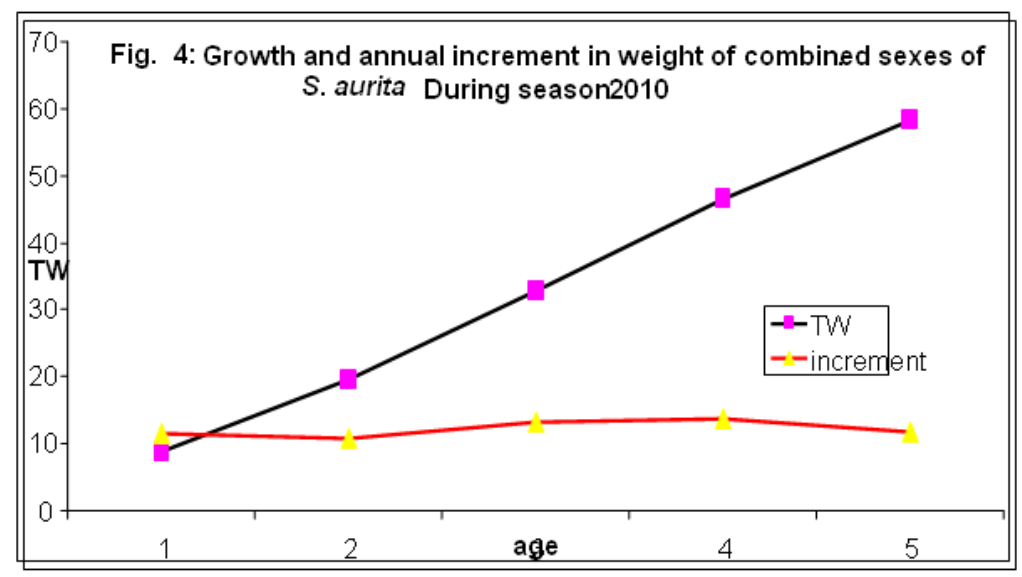

The result in the Table (4) show that the maximum value of annual weight increment successively and reaches its maximum at the end of fourth group of life.

\section{4- Growth parameter:}

The parameters of Von-Bertalanffy theoretical growth model $\left(\mathrm{L} \infty, \mathrm{K}\right.$ and $\left.\mathrm{t}_{0}\right)$ were calculated as $\mathrm{L} \infty=28.37 \mathrm{~cm}, \mathrm{~K}=0.2336 \mathrm{Yr}^{1}$ ant $\mathrm{t}_{0}=-0.9808$ ant the obtained equation was $\mathrm{L}_{\mathrm{t}}=28.37\left(1-\mathrm{e}^{-0.2336}{ }^{[\mathrm{t}+9808]}\right)$. The asymptotic length is higher the maximum observed length. The growth performance index for S. aurita was about 2.2742 .

\section{5-Mortality and Exploitation rates:}

The total mortality coefficient (Z) by different method for $S$. aurita from the Mediterranean coast of Sinai at season 2010 defined as the total loss by natural and fishing death of individuals. The mean total mortality $(\mathrm{Z}=0.8807)$. The natural mortality $\left(\mathrm{M}=0.3507 \mathrm{Yr}^{1}\right)$ versus fishing mortality $(\mathrm{F}=0.53)$. The current established exploitation rate was $0.60(\mathrm{E}=60 \%)$.

\section{6- Recruitment and yield per recruitment:}

Fig. (5) show that the fishing mortality $(\mathrm{F}=0.53$ and age at first capture $\left[\mathrm{T}_{\mathrm{c}}=1.64\right)$ or length at first capture $\left[\mathrm{L}_{\mathrm{c}}=13 \mathrm{~cm}\right]$ ) give a yield of $8.637 \mathrm{gm}$ per recruit. The maximum yield per recruit is obtained with fishing mortality coefficient is lower than the fishing mortality coefficient produce the maximum yield per recruit. This mean that increase of fishing mortality coefficient by a bout $32.2 \%$ from 0.53 to 0.7 would increased the yield per recruit by only $0.97 \%$. 


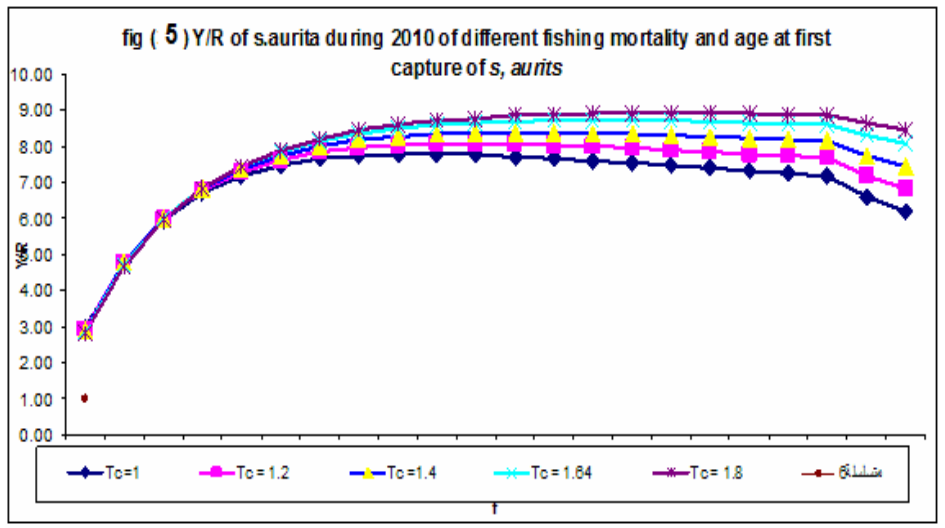

\section{DISCUSSION}

Present results indicated that the total catch from Mediterranean coast of Sinai fishery was pronounced it's fluctuation between lower catch 608 tons during 1990 and higher catch 11715 tons during 1999. This catch fluctuation was influenced by abundance of sardine. The decline in the catch of sardine recorded by 219 tons in 2010 and 310 tons in 1990. However, a positive correlation between total catch and catch of Sardine was observed $(\mathrm{r}=0.99)$. The composition of catch in the Mediterranean coast of Sinai fishery was slightly changed during the period, 1991 to 2008 where the sardine dominated in catch by over $70 \%$ from total catch. The fluctuation of catch may be due to availability of food and environmental changes. These results are in agreement with results by wadie (1998) where found that the several factors or responsible for construction of the high Dam. Tow important factors that effect the occurrence and abundance of Sardine shoals can be detected quality and quantity of food and some environmental changes that have acted in such a way so as to greatly reduce the survival rate of sardine eggs and larvae. Before 1965 the River Nile discharge was the main reason for the high biological productivity of the Shelf waters. This was due the large amounts of organic substances and mineral particles through its tow Tributaries (Damietta and Rosetta). Increases in sardine catch in recent years may be attributed to introduction of new fishing gear effective for sardine fisheries, in addition certain environmental changes occurred, that are favorable for high sardine production.

In the present study the power " $n$ " was 2.682 by using the length-weight relationship and when using the gutted weight the power " $n$ " was 2.6411 indicated acute negative allometric growths for $S$. aurita. The previous results for the same species show that " $n$ " value ranged from 2.4 to 3.179 according to EL-Aiatt, 2004 and 2.526 as reported by Salem et al., 2010, both results obtain from Mediterranean coast, EL-Arish. Also, agreement with EL-Maghraby et al., 1970 where found that the power "n" equal 2.4176. In spite of Abdalla and EL-Haweet (2000) and Faltas (1983) in studing the length-weight relationship of $S$. aurita in East and west Alexandria found sepratly that the value of power "n" 3.1793 and 3.1764 in East and 3.1482 in west Alexandria respectively. Also, Moutopoulos and Stergiou, 2002 mentioned that the power "n" for $S$. aurita was 2.804 and 3.12 respectively. The relationship between body length and weight can also be change with many condition factors as season, sex, food, matyrity stage and techniques, of sampling (Le-Cren 1951). The slightly negative allometric growth in AL-Arish, Mediterranean coast, may be related to unavailable of food and unsuitable of environment. 
The body length and scale radius relationship show a linear on their scatter diagram $\mathrm{L}=-0.6683+2.132 \mathrm{~S}$. This results agree with Salem et al., $2010(\mathrm{~L}=$ $-0.4847+2.0893 \mathrm{R}$ and with EL-Aiatt $(2004)[\mathrm{L}=-0.7994+2.1604 \mathrm{~S}$ at season 2000 and $L=-0.7670+2.1356 \mathrm{~S}$ at season 2001). The average back-calculation length at the end of each year was 10.6, 14.23, 17.26 and $19.66 \mathrm{~cm}$ for age 1, 2, 3, and 4 respectively. The obtained results showed the highest increment in length occurred at the first year $10.6 \mathrm{~cm}$ of $S$. aurita, after which the annual increment in length decreases with further increase in age. The length of Sardine, S. aurita in the present study was lower than that obtained by Faltas, 1983 where he found the length at the end of each year of the first fourth years for $S$. aurita 12.7, 15.9, 18.7 and $21 \mathrm{~cm}$ respectively. Also, Salem et al., 2010 where found the length at the end of the first fourth years for the same species at season 2007, 11.1, 14.7, 18.0 and $19.8 \mathrm{~cm}$. The obtained results by EL-Aiatt, 2004 where found the length at the end of the first fourth years for the same species 12.38, 15.91, 18.77 and 20.54 at season 2000 and 12.18, $15.23,18.56,20.02$ at season 2001 respectively.

In this study, there is a well agreement somewhat between the calculated length and calculated weight and length and weight by using Von-Bortalanffy equation.

The asymptotic length $(\mathrm{L} \infty=28.37)$, the body growth coefficient $(\mathrm{K}=0.2336$ Yr-1) and the maximum length $\left(\mathrm{L}_{\mathrm{Max}}=23.1\right)$ are different than most Mediterranean stock which obtained by Buaziz et al., $2001\left(\mathrm{~L}_{\mathrm{Max}}=25.5 ; \mathrm{L} \infty=34.96 ; \mathrm{K}=0.236 \mathrm{Yr}^{-1}\right.$ in Algeria coast and Gaamour et al., $2001\left(\mathrm{~L}_{\mathrm{Max}}=27.35 ; \mathrm{L} \infty=31.32 ; \mathrm{K}=0.240 \mathrm{Yr}^{-1}\right)$ in Tunisia coast, the hypothetical age at which a fish would have Zero length $\left(\mathrm{t}_{0}=\right.$ 0.9808) similar which obtained by Buaziz et al., $2001\left(\mathrm{t}_{0}=-0.717\right)$ and Salem et al., $2010\left(\mathrm{t}_{0}=-0.878\right)$ for the same species. Differences in growth parameter may be due to genetic structure; temperature, food available and diseases (Pauly, 1994 and Wooton, 1998).

The index of growth performance $(\varnothing)$ is considered a useful tool for comparing the growth curves of different populations of the same species and/or of different species belonging to the same family (Gayanilo and Pauly, 1997; Sparre and Venema, 1992).

In this study, the value of growth performance $(\varnothing=2.27)$. This result is agreed with Gammour et al., $2001 \quad(\varnothing=2.27)$ in Tunisia coast, and Salem et al., 2010 in Mediterranean coast of Sinai, but lower compared with Chesheva, $1998(\varnothing=2.66)$ in Mouretania coast. In the Mediterranean sea, the mean index of growth performance is lower than for the another regions (Tsikliras et al., 2005).

Several methods were used for estimating the total mortality coefficient. In the present study, the results estimation of annual total mortality coefficient $(\mathrm{Z})$, defind as the total loss by natural and fishing death of individuals as $0.8807 \mathrm{Yr}^{-1}$. Different results were obtained by Hashem and Faltas, 1982 estimated the total mortality for $S$. aurita in Alexandria region (1.377). Salem (2010) 1.49 and EL-Aiatt, 2004 (1.262) and (1.519) in season 2000 and 2001 respectively for $S$. aurita in EL-Arish region.

The natural mortality $\left(0.3507 \mathrm{Yr}^{-1}\right)$ versus fish mortality $(0.53)$ observed for $S$. aurita indicated the balanced position of the stock. The natural mortality is the mortality created by all other causes than fishing, such as perdition including cannibalism, diseases, spawning street, starvation and old age. Perdition and starvation mortality are linked to the ambient ecosystem. The same species may have different natural mortality rates in different areas depending on the density of predators and competitor's whose abundance is influenced by fish activities (Sparre and Venema, 1992). Gulland, 1971 suggested that, fishing mortality should be about equal to natural mortality, resulting in an exploitation rate of $0.5 \mathrm{Year}^{-1}$. However, 
exploitation rates should be very conservative for relatively long lived species (Newman and Dunk, 2003). In this work the current established exploitation rate was $0.60(\mathrm{E}=60 \%)$. The current exploitation rate is optimally exploited stock $(50 \%)$ according to Gulland (1971). Salem et al., 2010 mentioned for S. aurita in EL-Arish region, the optimum exploitation rate which produces maximum and economic sustenable yield $\left(\mathrm{E}_{\mathrm{Max}}=0.87\right.$ and $\left.\mathrm{E}_{0.1}=0.71\right)$. in our study the curren exploitation rate is less than the predicted $\left(\mathrm{E}_{\mathrm{Max}}\right)$ and $\left(\mathrm{E}_{0.1}\right)$, where this mean that the stock is not overexploited.

Results of recruitment and yield per recruitment show that the maximum yield per recruit is obtained with fishing mortality coefficient 0.7 . This means the present level of fishing mortality coefficient is lower than the fishing mortality coefficient produces the maximum yield per recruit. Also, this mean that increase of fishing mortality coefficient by about $32.1 \%$ from 0.53 to 0.7 would increased the yield per recruit by only $0.97 \%$.

In conclusion, the natural mortality $\left(0.3507 \mathrm{Yr}^{-1}\right)$ versus fish mortality $(0.53)$ observed for $S$. aurita in north fishery indicates the balanced position of the stock. The current exploitation rate is less than the predicted $\left(\mathrm{E}_{\mathrm{Max}}\right)$ and $\left(\mathrm{E}_{0.1}\right)$, where this means that the stock is not overexploitation. In north Sinai fishery, the mean index of growth performance is lower than for the another regions, may be related to unavailable of food and unsuitable of environment.

\section{REFERENCES}

Abdalla, M. and EL-Haweet, A. E. (2000): Stock assessment of sardine in the Egyptian Mediterranean water by Virtual population analysis: Case for the cost for the coast for Alexandria to Abo-qir, Egypt. J. Aquat. Biolx Fish. 4. No. 3: 173-191.

Ben-Tuvia, A. (1958): Some studies on Sardina pilchrdus from the coast of Israel. Gen. Fish counc. for the Mediter., 5.

Bouaziz, A.; Bennoui; B. Brahimi; R. Semroud (2001): Sur l'esimation de L'etat d'exploitation de la sardine (Sardinella aurita Valenciennes, 1847) de la region center de la cote Algerian. Rapp. Comm. int. Medit., 36-244.

Chesheva, Z. A. (1998): The method for determining age and growth rate of gilt sardines Sardinella aurita in the Senegal-Mauritania population. J. Ichthyol., 38: 814-817.

EL-Aiatt, A. A. O. (2004): Study on fish production of the Mediterranean coast of Sinai. Theses, PhD, Faculty of Environmental Agricultural Sciences, Suez Canal University.

EL-Maghraby, A. M.; Botros., G. A. and Soliman, I. A. M. (1970): Age and growth study on Sardinella Maderensis Lowe and Sardinella aurita Cuv. and Val. from the Mediterranean Sea at Alex. (U.A.R.) Bull. Inst. Oceanogr. and Fish., U. A. R. 1: 47-82.

Faltas, S. N. (1983): Study of purse-siene fisheries in Egyptian Mediterranean Water with special reference to the biology of sardine in the catch. M. Sc. Thesis, Faculty of Scince, University of Alexandria. 194pp.

Ford, E. (1933): An account of the herring investigation conducted at Ply Mouth. J. Marin. Biol. Ass. U.K., Vol. 19: 305-384.

Gaamour, A.; Missaoui, H; Ben-Abdallah, L. and EL-Ahmed, A. (2001): Parameters biologiques de la Sardinelle rounde (Sadinella aurita valenciennes, 1847) dans 
la vegion du cap bon (Cana; siculo-Tunisien). GFCM, 26-30 march 2001. Kavala, Greece. (www.faocopemrd.org/en/ sac/docs.htm).

Gayanilo, F. C. and D. Pauly (1997): FAO-ICLARM stock assessment tools. Reference manual. ICLARM International Center for Living Aquatic Resources Management Food and Agriculture Organisation of the United Nation. Rome, pp. 262.

Gulland, J. A. (1971): The fish resources of the Ocean, Fishing News Books, Ltd, West Byfleet, UK, 225p.

Gulland, J. A. (1969): Manual of method for fish stock assessment, part1: Fish population analysis FAO Man. Fish Sci., 4: 1-154

Hashem, M. T. and Faltas, S. N. (1982): Fisheries investigation of the Sardine gill net at EL-Mex Region, near Alexandria. Bull. Inst. Oceanogr. and Fish., ARE, Vol. 8 (2): 197-155P.

Le Cren, E. D. (1951): The length-weight relationship and seasonal cycle in gonad weight and condition in perch (Perca fluviatilis). J. Anim. Ecol., 20: 201-219.

Lea, E. (1910): On The methods used in the herring investigations. Publ. Circonstance, cons. Int. Explor. Mer., 53: 7-174

Martin, W. R. (1949): The mechanics of environmental control of body form in fishes. Univ. Toronto. Stud. Biol. 58: 1-91.

Moutopoulos, D. K. and Stergious, K. I. (2002): Weight-length and length-length relationships for 40 fish species of the Aegean sea (Hellas). J. Appl. Ichthyol., 18: 200-203

Munro, J. L. and Pauly (1983): A simple method for comparing growth of fishes and invertebrates. ICLARM Fishbyte, 1 (1): 5-6.

Newman, S. J. and Dunk, I. J. (2003): Age validation, growth, mortality and additional population parameters of the goldband snapper (Pristipomoides multi dens) off the Kimberley coast of northwestern Australia. Fish. Bull., 101: 116128.

Paul, L. J. (1968): Early scale growth characteristics of the New Zealand, Sparus aurata (Forster), with reference to selection of scale-sampling site. N. Z. J. Marine and Fresh water Res., 2: 273-292.

Pauly, D. (1994): On the sex of the fish and the Gender of Scientists Chapman and Hall, London.

Pauly, D. (1980): A selection of simle methods for the assessment of tropical fish stock. F.A.O. Fish. Cire., No. 729. F/RM/C701.p54.

Salem, M.; EL-Aiatt, A. A and Ameran, M. (2010): Age, growth, mortality and Exploitation rates of round Sardinella (Sardinella aurita) from the east Mediterranean sea (north Sinai coast) Research Journal of Fisheries and Hydtobiology, 5 (1): 32-38.

Sionvcic, G.; Franicevic, M. and cikes Kec, V. (2004): Unusual occurrence and some aspects of biology of juvenile gilt sardine (Sardinella aurita valenciennes, 1847) in the Zrmania River estuary (eastern Adriatic). Journal of Applied Ichthyology, 20: 53-57.

Sparre, P. and S. C. Venema (1992): Introduction to tropical fish stock 992 assessment. Part 1 manual., FAO Fish. Tech. pap. 306/1 Rev., 1:376.

Tsikliras, A. C.; E. Koutrakis; K. Stergious (2005): Age and growth of round Sardinella (Sardinella aurita) in northeastern Mediterranean Scientia Marine, 69: 231-240.

Von Bertalanffy, L. (1949): Problems of organic growth, nature, 163: 156-158. 
Von Bertalanffy, L. (1934): Unretersuchungen uber die Geselzlichkeit des wachstums. I. Allgernine Grundlag der theorie. Willherm Rouse. Arch. Entumech. Org., 131: 613-653.

Wadie, W. F. (1998): Impact of Damming on sardine catch in the south Estern Mediterranean. J. Egypt. Ger. Soc. Zool., 25 (B):341-258.

WalFord, L. A. (1946): A new graphic method of describing the growth of animals. Mar. Biol. Bull. 90 (2): 141-147.

Whitney, R. R. and carlender, K. D. (1956): In temperature of body Scale regression for competing body length of fish. J. wild. Management: 20: 21-27.

Wooton, R. J. (1998): Ecology of Teleost. Fishes. Kluwer Academic Publishers, Dordrecht.

\section{Arabic Summary}

$$
\begin{aligned}
& \text { تقييم المخزون وادارة مصايد اسماك السردين المبروم فى ساحل شرق البحر الابيض المتوسط }
\end{aligned}
$$

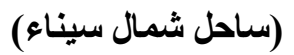

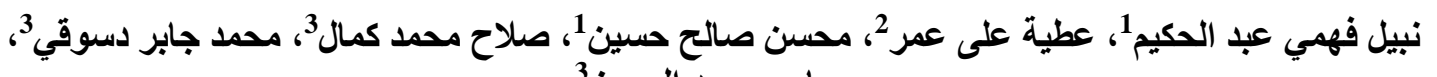

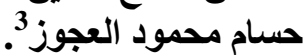

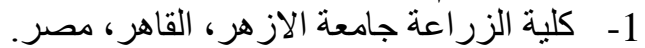

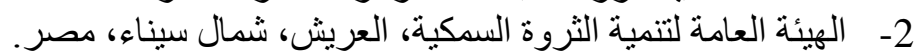

$$
\begin{aligned}
& \text { 3- قسم الاستزر اع السمكي، المعمل المركزي لبحوث الثروة السمكية، العباسة، ابو حماد، شرقية، مصن، مصر. } \\
& \text { تم جمع عينات من اسماك السردين المبروم شهريا من يناير الى ديسمبر (2010) من مصايد شرق البحر }
\end{aligned}
$$

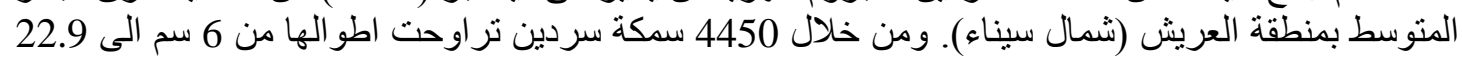

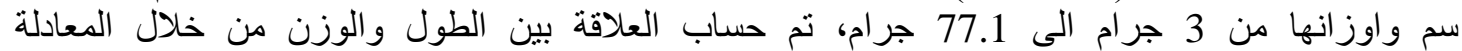

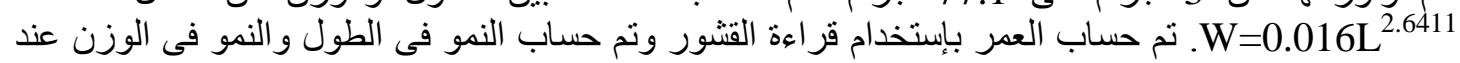

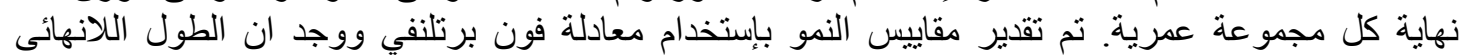

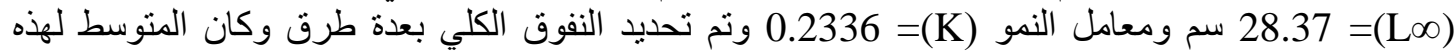

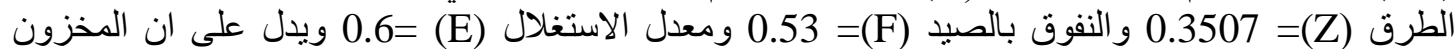

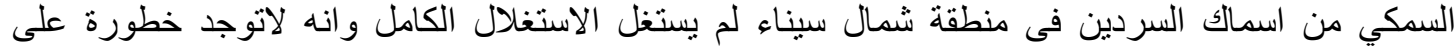

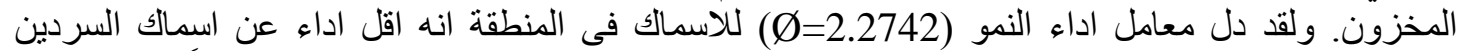

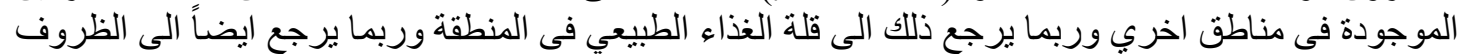

$$
\begin{aligned}
& \text { البيئية غير المناسبة لنمو السردين. }
\end{aligned}
$$

